\title{
EVENTO OSWALDIANO
}

O grande poeta e ensaísta americano manifestava ao auditório lotado suas afinidades com a literatura em meio à leitura de seus poemas barrocos. Solicitado a reafirmá-lo por um jovem centroavante da vanguarda o grande poeta e ensaísta mexicano reiterou suas afinidades com a literatura da vanguarda em meio à leitura de seus poemas barrocos.

Mas quem roubava a cena era uma fotógrafa esguia de blusinha curta e jeans Saint-Tropez que para flagrar o grande poeta e ensaísta mexicano em poses de vanguarda

fazia tais malabarismos com o corpo elástico

exibia tamanho maleável no contorcionismo grácil

tantas posições arriscava atirando os cabelos

ora na pontinha dos pés

ora curvada nos joelhos

ora semi-deitada no lânguido carpete vermelho

que os rapazes e senhores mui entusiasmados não mediram aplausos ao fecho da sessão, o que deixou sinceramente comovidos o grande poeta e ensaísta mexicano e o pessoal da vanguarda.

AlcidesVillaça

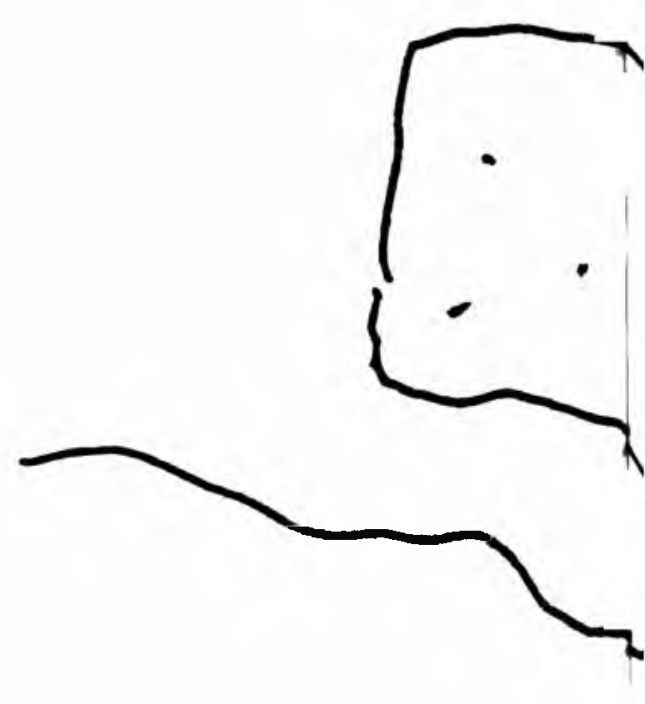

